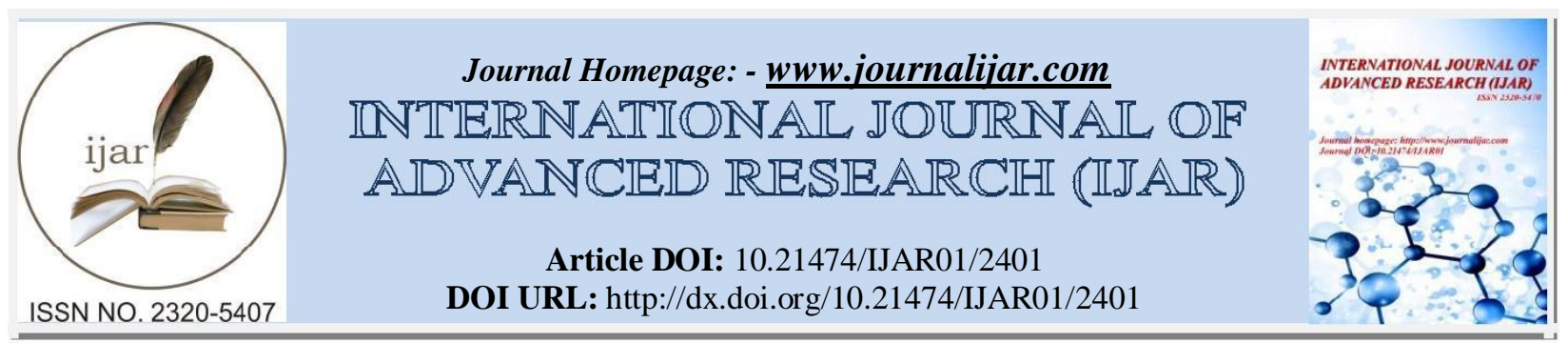

RESEARCH ARTICLE

VIRTUAL KEYBOARD.

\title{
A STUDY OF SECONDARY SCHOOL TEACHERS ENTREPRENEURIAL MOTIVATION IN RELATION TO THEIR ENTREPRENEURIAL COMPETENCIES.
}

\author{
Ms. Vaishali Tadvi and Dr. Sunita Magre ${ }^{2}$. \\ 1. Assistant Professor, H. B. B. Ed College, Vashi. \\ 2. Ph. D Guide, Associate Professor (HOD), Department of Education, Kalina.
}

\section{Manuscript Info}

...........................

Manuscript History

Received: 19 October 2016

Final Accepted: 20 November 2016

Published: December 2016

\section{Abstract}

Copy Right, IJAR, 2016,. All rights reserved.

\section{Introduction:-}

Teacher will need a broad array of entrepreneurial competency to succeed in today education market. They must possess basic competency and potential necessary to enable them function effectively and there by increases the employability level of their school products. Teacher needs some essential entrepreneurial competency and potential that will increase their efficiency and effectiveness in knowledge delivery and management of resources in the school environment these include: instructional leadership, management, communication, vision development evaluation, analysis competency.

Competencies equip you with the knowledge of how to do ('know-how') of entrepreneurial behavior and motivation provides answers to why to do ('know-why') of entrepreneurial behavior. Entrepreneurship, successful performance of the venture itself becomes a reward for the entrepreneur.

This is because they would have become competent enough to visualize and recognize employment opportunity. These traits are the qualities a teacher should encourage in higher education students for them to be able to start up enterprise. For active citizenship, employment and social cohesion. These build one's future on professional and personal level, and high quality education is essential for this purpose. The reliability of work depends upon its competency and competency depends upon consistency of that work and motivation.

Teachers have a central role, as they have a strong impact on the attainment of learners.

Reflective teachers keep their practice under constant review and adjust it in the light of desired learning outcomes and of the individual needs of students. As a key competence, entrepreneurship does not necessarily involve a specific school subject. Rather, it requires a way of teaching in which experiential learning and project work have a main role. Teachers do not provide students with the answers, but help them to research and identify the right questions and find the best answers. To inspire their pupils and students, and to help them develop an enterprising attitude, teachers need a wide range of competences related to creativity and entrepreneurship; they require a school environment where creativity and risk-taking are encouraged, and mistakes are valued as a learning opportunity. 
Developing the competences of school leaders and teaching staff — including aspiring new teachers.so the entrepreneurial motivation work has essential role on entrepreneurial competencies.

\section{Operational Definitions Of The Terms:-}

The definition of the terms used by the researcher is as follows:

Entrepreneurial Motivation: Entrepreneurs are concerned mainly with influencing the environment, individuals and institutions to achieve their goals. It also included entrepreneurial core, work core, social core, individual core and economic core.

Entrepreneurial Competencies - the sum of our experiences and the knowledge, skills, values and attitudes we have acquired during our lifetime, which are necessary for effective performance in a job or life role. It also included initiative, concern for high quality of work, problem solving, and self-confidence.

Secondary School Teachers: Teacher having graduated or postgraduate degree with B.Ed has a professional qualification and are teaching $9^{\text {th }}$ to $10^{\text {th }}$ standard of SSC, ICSE and CBSE boards.

\section{Objective Of The Study:-}

To ascertain relationship of entrepreneurial motivation of secondary school teachers with entrepreneurial competencies on the basis of gender.

\section{Hypothesis:-}

1) There is no significant differences between of secondary school teachers entrepreneurial competencies(EC) on the basis of gender.

\section{Sampling:-}

The data were collected from the $9^{\text {th }}$ and $10^{\text {th }}$ Standard English medium school situated in Navi Mumbai.The researcher employed stratified random sampling.

\section{Tools Of The Research:-}

In order to achieve the objective of the study, the investigator would use the following tools:

1. Entrepreneurial Motivation Scale-(V.Vijaya and T.J.Kamalanabham,2009)

2. Entrepreneurial Competencies Scale (entrepreneurship development institute of India, Ahmadabad.)

\section{Methodlogy Of Research:-}

In order to achieve the objective of the present investigation, Descriptive, Comparative and Correlation method would be adopted.

\section{Techniques Of Data Analysis:-}

For the purpose of the present study, the researcher will carry out the descriptive and inferential analysis in order to process data.

\section{Testing Hypothesis-1.1}

The null hypothesis states that there is no significant difference between of secondary school teachers entrepreneurial motivation (EM) on the basis of gender. The technique used to ' $t$ ' test

Table 1.1 gives numerical data and level of significance for ' $t$ '.

Table 1.1:- Difference in scores on Entrepreneurial Motivation of secondary school teachers on the basis of Gender

\begin{tabular}{|c|c|c|c|c|c|c|c|c|c|}
\hline & & & & & & \multicolumn{2}{|c|}{ Table value ' $t$ ' } & 't' ratio & Sig.level \\
\hline Variable & Group & $\begin{array}{l}\text { Sample } \\
\text { size }\end{array}$ & $\overline{\mathrm{Df}}$ & mean & SD & 0.05 & 0.01 & & \\
\hline \multirow[t]{2}{*}{ Gender } & Male & 48 & \multirow[t]{2}{*}{311} & 102.3125 & 2.57 & \multirow[t]{2}{*}{1.98} & \multirow[t]{2}{*}{2.61} & \multirow[t]{2}{*}{11.79} & \multirow[t]{2}{*}{0.01} \\
\hline & Female & 265 & & 77.6415 & 14.44 & & & & \\
\hline
\end{tabular}

\section{Inference:-}

From the table 1.1 it can be seen that $\mathrm{t}$ ratio at 0.05 and 0.01 level of significance is 1.98 and 2.61 respectively. The obtained t-ratio is 11.79 which is exceed than the tabulated value at 0.01 level of significance and hence the null hypothesis is rejected. 


\section{Conclusion:-}

There is significant difference in the teachers entrepreneurial motivation on the basis of gender.

\section{Interpretation:-}

The finding revealed that both male and female teachers differ in their entrepreneurial motivation. They differs in entrepreneurial motivation such as entrepreneurial core, work core, social core, individual core and economic core. Hence it can be concluded that there is significant differences in entrepreneurial motivation of secondary school teachers on the basis of gender.

\section{Testing Hypothesis-1.2}

The null hypothesis states that there is no significant difference between of secondary school teachers entrepreneurial competencies(EC) on the basis of gender. The technique used to ' $\mathrm{t}$ ' test

Table 1.2 gives numerical data and level of significance for ' $t$ '.

Table 1.2:- Difference in scores on Entrepreneurial Competencies of secondary school teachers on the basis of Gender.

\begin{tabular}{|l|l|l|l|l|l|l|l|l|l|l|}
\hline & & & & \multicolumn{3}{|l|}{ Table value 't' } & 't' ratio & Sig.level \\
\hline variable & Group & $\begin{array}{l}\text { Sample } \\
\text { size }\end{array}$ & Df & mean & SD & 0.05 & 0.01 & & \\
\hline Gender & Male & 48 & 311 & 249.9167 & 10.10 & 1.98 & 2.61 & 11.21 & 0.01 \\
\cline { 1 - 6 } & Female & 265 & & 213.0566 & 22.35 & & & & \\
\hline
\end{tabular}

\section{Inference:-}

From the table 1.2 it can be seen that $t$ ratio at 0.05 and 0.01 level of significance is 1.98 and 2.61 respectively. The obtained t-ratio is 11.21 which is exceed than the tabulated value at 0.01 level of significance and hence the null hypothesis is rejected.

\section{Conclusion:-}

There is significant differences in the teachers entrepreneurial competencies on the basis of gender.

\section{Interpretation}

The finding revealed that both male and female teachers differ in their entrepreneurial competencies. They differ inentrepreneurial competencies such as intiative ,problem solving,selfconfidences, use of strategies. Hence it can be concluded that there is significant differences inentrepreneurial competencies of secondary school teachers on the basis of gender.

\section{Finding of The Study:-}

The null hypothesis have been tested using appropriate parameter and non parameter statistical techniques. The major finding of the study are as follows.

1.1The null hypothesis 1.1 was tested ' $t$ ' was found to 11.79 which is significant at 0.01 level.hence the null hypothesis is rejected.it was found that there is significant positive and high relationship between the entrepreneurial motivation and entrepreneurial competencies of than the male teachers.

1.2 The null hypothesis 1.2 was tested using the ' $t$ 'test was found to be found 11.21 which is significant at 0.01 level.hence the null hypothesis is rejected.it was found that there is significant difference of entrepreneurial competencies on the basis of gender.

\section{Discussion:-}

1) The personal responsibility is assigned for goal achievement.

Total freedom be given to them to set their goals. For the results of the efforts, proper and without any prejudice, information feedback is provided to them.

Work should be assigned to do in a moderate risk conditions.

Proper recognition and appropriate returns be given according to the work done successfully.

2)The motivational pattern of men and women entrepreneurs it may be said that typically a man's motivation arises from disagreement with established authority or a feeling that 'I can manage things better', coupled with the drive to control one's own destiny.

For women, the reason seems to be different. As they are not allowed to perform at the level they are capable of in their work. 
The major source sources of motivation for women could thus be need to achieve, desire to be independent.

Need for job satisfaction. Economic necessity, desire to make use of one's talent, skill, and the desire to be one's own boss.

Female are often motivated by desire to have flexibility in their work and family.

\section{Significance Of The Study:-}

Since teachers play a major role in the development of students. The finding will be very useful for both prospective and practicing teacher. Mechanism for actualizing an opportunity often initially exists mainly in the entrepreneurs mind, making the entrepreneurs idea for how to exploit the opportunity a personal interpretation of the opportunity. This idea is basically what we would call vision. Such judgment may be mistaken: entrepreneurs sometimes believe that they have identified valuable opportunities. A teacher tends to be innovative with different approaches to achieve the goals. Teachers always prepared to try out alternatives. For them, the method of choice is the method which will work best. So, if the common sense approach fails, they will invent new ones. They are ingenious at adapting and modifying whatever is at hand to solve the problems or achieve the objective. It will be helpful to identify the secondary school teachers' competency in the subject as well as teaching techniques. This study also helpful to find out secondary school teachers potential that has a great impact on students character building. This study can be helpful for principle to accept responsibility for ones actions. Accept full responsibility for success or failure. Motivated teachers, students to achievement and recognize opportunity.

\section{References:-}

1. Albanese, R. (1989). Competency-based management education. Journal of Management Development.8(2), 66-76.

2. Aldrich, H. and Zimrner, C. (1986). Entrepreneurship through social networks, in D.L.

3. Sexton and R.W. Smilor (Eds.). The Art and Science of Entrepreneurship. 2-23.

4. Cambridge, MA: Ballinger Publishing Co.

5. Barkham, R.J. (1994). Entrepreneurial characteristics and the size of the new firm: a model and an econometric test. Small Business Economics. 6(2), 117-125.

6. Bartlett, C.A. and Ghoshal, S. (1997). The myth of the generic manager new personal competencies for new management roles. California Management Review. 40(1),

7. Baum, J.R., Locke, E.A. and Smith, K.G. (2001). A multidimensional model of venturegrowth. Academy of Management Journal. 44(2), 292-302.

8. Begley, T.M. and Boyd, D.P. (1985) Company and chief executive officer characteristics related to financial performance in smaller businesses. In Frontiers of Entrepreneurship Research. MA: Babson College, 146-165.

9. Begley, T.M. and Boyd, D.P. (1987). Psychological characteristics associated with performance in entrepreneurial firms and smaller business.Journal of Business Venturing,2(1).79-93

10. Bergevoet, R.H.M., Giesen, G.W.J., Saatkamp, H.W., Woerkum, C.M.J. van and

11. Burgoyne, J. (1988). Competency Approaches to Management Development. Centre for the Study of Management Learning, University of Lancaster, UK.

12. Busenitz, L. W. and Barney, J. B. (1997). Difference between entrepreneurs and managers in large organizations: Biases and heuristics in strategic decision-making. Journal of Business Venturing. 12(1), 9-30.

13. Chandler, G.N. and Jansen, E. (1992). The founder's self-assessed competence and venture performance. Journal of Business Venturing. 7(3), 223-236.

14. Chandler, G. N. and Hanks, S. H. (1994). Founder competence, the environment, and venture performance.Entrepreneurship Theory and Practice.18(3).77-89

15. Changanti, R. and Parasuraman, S. (1996). A study of the impacts of gender on business performance and management patterns in small businesses.

16. Entrepreneurship Theory and Practice. 21(2), 73-75. 